\title{
Tracing the constructed 'modern' Turkish women identity in white goods commercials
}

Established in 1923, Turkish Republic has mostly been ruled around a major ideal goal for 90 years: "reaching to the level of contemporary civilizations". As this motto indicates, the ideal goal for the nation has been set around Western civilizations: being like modern Western countries, living Western lifestyles, wearing Western clothing, etc. In fact, in this geography modernization and Westernization ideal can be dated back to late 19th century. Starting from Ottoman Empire, these are seen as path to a peak point to be reached for becoming a developed and civilized country. However, society which has not completed industrialization, could not internalized modernization totally and therefore mostly adopted the outcomes of it from West. Thus, the modernization project, especially that are about daily life are realized over the constructed identity of women. They are regarded as the face value of a 'modern' country. In this regard, this paper tries to trace the created 'modern Turkish woman' identity embedded in Turkey's history, and link this identity to today's women by subjecting two white goods commercials, one from 80 and one from 2000 s.

keywords women identity, Turkey, commercial, modernization

\section{Background}

Modernization is defined to adopt and apply the norms, attitudes, and life standards of modern countries by the developing ones (Mardin,1991). These attempts started from the Ottoman Empire in 19th century and rapidly increased and applied after the announcement of the republic in Turkey in 1923. In this period, these attempts shifted into a goal to become one of the modern civilized societies (Biricikoğlu,2006). However, as an agricultural society for centuries, industrialization could not be a part of Turkish modernization. Accordingly, modernity projects could not be accomplished in economic aspects and remained limited within the modernization of cultural and social life. Thus, being 'modern' for Turkish society generally represents to be like West, but cannot go far away from a figurative replica of them. Moreover, for a country that tries to be 'modern' for two centuries, these modernization understanding is not able to be perceived and embraced similarly across all over Turkey (Yiğit,2008).

Although modernization in Turkey seemed to a political and economic decisions made by the government, it revealed itself on daily life, especially on women's, and women became the carriers of the modernization project. Most of the adjustments of the new republic were about replacing religious based politics and values with the secular ones, which significantly transformed the role of women in social life. Promulgated reforms to reach to a civilized level; like new dressing codes, right to vote and selected, educational rights, 
access to professional employment, etc.; made women the symbol of 'modern' Turkey (Biricikoğlu,2006). Their visibility in social life changed the perception of women, whom before then regarded as the commodity of her husband, family, village or the government (Toktaş,2002). These reforms allowed them to get a role outside their domestic borders (Kandiyoti,1993). Although these social, legal, and political reforms were applicable for few urban women who had higher socioeconomic backgrounds; the policies of the government were determined to make those women as a representative of the new republic (Müftüler-Bac,1999), as an ideal model for all Turkish women. In this very elitist perspective, every woman was expected to wear like the ideal 'modern' Turkish woman, get educated like them and stand on their own feet like them. Turkish women embraced the reforms and support these modernist values; they internalized these expectations and were proud to be part of the social life; and they finally found the hope to end their subordinate position in the society (Toktaș,2002).

Another social change that affected the 'modern Turkish women' identity was occurred by the changing consumption practices of the society. Turkish society, which was once proud of their savings, has become a consumer society after adopting the neo-liberal economy policy in 8os which opens the gates of the country to foreign goods and services. New shopping and entertainment areas were emerged, the advertising industry grew and a consumption oriented new urban middle class was developed during 805 (SandıkçıGer,2007). The imported goods made the country look abundant and the consumption increased rapidly. Turkish people who suffered from not meeting their basic needs for long years began to experience the pleasure of consumption that has become another rule to be the 'modern' (Yavuz,2013).

Advertising guided, society which was confused by the emergence of new goods and supported consumption by creating needs and showing social clues to meet these needs. They offered audience stereotyped identities, made myths and ideologies develop and cycle across the society. So, consumers began to learn using symbolic meanings of goods to position themselves socially and to express their identity. Especially the ones that increased their wealth after 1980 os formed a new target group for the advertisers. Advertisers preferred messages that will take this new urban middle class; young, educated and wealthy group's attention (Yavuz,2013).

In developing countries like Turkey, advertising doesn't work as the mirror of the society, but moulds it according to the ideal modern lifestyles. Developments in media had also an additive effect on consumerism. The variety and free choice of private TV channels made television to be a crucial part of the daily life. Thus, commercials presentation of idealized life standards became more ubiquitous than ever. People accepted even cherished these life standards and compete each other to reach these ideals by consuming. Gender representation is another point that media texts offered to society. Since meanings and values are constructed socially (Althusser,1971), these texts propose certain roles and profiles for gender that promoted the republican, modern Turkish woman, who is educated and employed.

Starting from new republican period, it can be seen that the ideal 'modern Turkish woman' identity is constructed on urbanized, educated, employed and economically self reliant character. However, if we look at the today's variables, it is quite different from the projection of the ideal women of Turkish modernity. In their report based on the governmental data of 2005, Sancar\&Bulut (2006) state that in Turkey $61 \%$ of total female population lives in urban areas and $15,9 \%$ of them are working; this is the $\% 9,85$ of total 
female population. This data indicates that the ideal Turkish women identity could not spread throughout whole nation.

\section{The Study}

Commercials not only introduce goods to society in utility manners, but they also offer idealized characters who have lots of subtexts to uncover. To reach these hidden meanings, semiotic analysis, which offers researchers to illustrate their points with carefully selected samples (Leiss et al,1997/2009), is adopted to analyse two commercials; one from 1980 s and one from 2007; for the study. They present dramatic representatives of 'ideal women' of the times.

\subsection{Case I: 1980s Arçelik commercial}
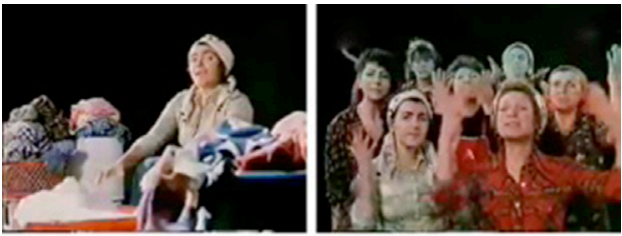

Figure 1.

Screenshots from 1980 Arçelik washing machine commercial

In this commercial from 8os, first we see the rural women who are hand washing the laundry. They wear rural clothes; baggy trousers, long skirts and t-shirts made of chintz and head scarves. In this first part of the advertisement, we see a black background behind the women. They are singing the jingle in which they are complaining about the entire process of laundry, and then they get together, open their hands to God and ask to end their misery. After we see the washing machine in a close up shot, the camera zooms out and we see the women near the washing machine. Their clothes are changed to skirts and shirts and they are standing in front of a white background. They again raise their arms in the air; however this time with joy.

The commercial can be divided into two parts; first, the users with the product; second, without. In the first part, the clothes make us think that the women belong to a lower social class or rural. They are defined as housewives who devote themselves to housework, but also tired of it. In the second part, the women changed their clothes, even one them wears a suit. They look classy like business women. After product is shown, we see a sudden upgrade in the appearance and social status of the women.

The commercial underlines the ease that the product will bring to the users' lives. However, it promises other things besides an easier laundry process; having the washing machine will end their misery. In this commercial we see the modern - traditional conflict clearly. Living in rural, wearing baggy trousers and headscarves, dealing with laundry for 
theme 2

memory

Figure 2.

Screenshots from 2007 Profilo washing machine commercial strand 2

design culture

a whole day are derogatory and represents being miserable according to the discourse of 8 os. However, urban life standards, business clothes, being part of the social life, taking care of yourself, having spare time are defined as the 'should have's of 80 s. In this commercial the shift in the perception is realised by the changes of clothes. As Schudson (1989) stated, fashion, comparing to other consumption patterns, is the most practical and best way to present identity. This situation is obvious in this commercial; changing the clothes, pretty much changed everything about these women. They suddenly upgrade in the social strata, get educated, professionally employed and most importantly they became 'modern'.
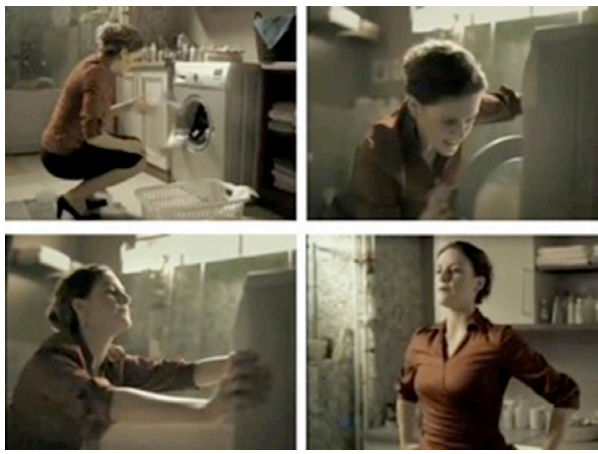

\subsection{Case II: 2007 Profilo commercial}

In this commercial from 2007, we see a woman crouched down in front of a washing machine and putting dirty clothes into a washing machine while murmuring about her woman colleague who took the credits of a report on which she worked for 3 months. She gets really upset and seems very angry; wreaks her anger on the washing machine. After she slams the door of the machine several times, she takes a deep breath and calms down. She turns on the washing machine when the narrator of the commercial says "In life, everybody should be as though as Profilos, should challenge the years and the difficulties." After that, we see the woman made her mind up and said she is not an easy picking. She tidies herself up and seems ready for the challenge.

She is wearing her business clothes and high heels. We understand that she just came home from work and engaged to housework. In everyday life sometimes we get angry and wreak our anger on products; this is used nicely to underline durability and toughness of the product. However, in this commercial, unlike the traditional ones, we are not informed about the specific features of the product. The plot is designed as a life section of a woman from $21^{\text {th }}$ century.

The woman presented in the commercial is a modern business woman who embraces the technology and its products and adopts them into her life. Owning this washing machine is not a life changing event for her. Being a business woman is a normal thing for her, she has a career as expected from her. Thus, being a 'modern' woman is normalized. However, she needs to struggle issues about work now. She is ambitious and doesn't feel comfortable to give all credits of her work to another colleague who is also a woman. 


\section{Conclusion}

If we consider these two commercials nearly 25 years apart from each other, we can see that the expectations from a modern Turkish woman have not changed dramatically. The first commercial emphasizes that the life-standards of modern Turkish women can be achieved by embracing technology and providing of it. We see the transformation of traditional women to a modern one. On the other hand, in the second commercial being 'modern' is taken for granted. It is presented as if it is the general case for a Turkish woman. She is not ambitious to get a job, since it is a normal thing for her; but now she has ambitions about the job.

However, both commercials indicate that modern Turkish woman should be educated, have a profession and maintain her life independent from the men. These circumstances are laid down as conditions in front of women to be part of the modern life.. These also are reflected to the appearance of women. There is no woman who "makes broom out of her hair"1 as in a Turkish saying, but there are women who suited up.

In this study, I tried to present the perception of 'ideal' woman of Turkish society by subjecting two commercials and support the outcomes with background information about Turkey. It can be said that; women are used as an instrument in behalf of the modernization project of Turkey; although society agreed upon the 'idealized woman character', statistics shows that these women are very few in number in reality; and despite these facts, 'modern woman' discourse is still used and encouraged as an ideology.

It can be said that, to reach modern standards, modernization is offered as a path to walk to developing countries, all of which experience their own way of modernization. In Turkish modernization process, one of these ways is realized over women as subjected in the paper. However, modernization movements that are maintained over women will always remain as a process for Turkey, because the ideal modern women subjected in the commercials and imposed to society via commercials, are not internalized by the society. Thus, Turkey will never be a part of Western World, because the adopted model of modernization to daily life anchored to different and complex standing points (Esenbel,2000).

\section{References}

Althusser, L.(1971) Ideology and ideological state apparatuses, in Lenin and philosophy and other essays. pp. 127-86. London:New Left Books.

Biricikoğlu, H.(2006) Türk modernleșmesinde kadın in proceedings from 2nd International Conference on Women's Studies:Breaking the Glass Ceiling. North Cyprus:Famagusta.

Esenbel, S.(2000) 'Türk ve Japon modernleșmesi: Uygarlık süreci'kavramı açısından bir mukayese', Toplum ve Bilim, vol.18, pp. 18-36.

Kandiyoti, D.(1993) 'Ataerkil örüntüler: Türk toplumunda erkek egemenliğinin çözümlenmesine yönelik notlar', in Tekeli, Ș. (ed.), 1980'ler Türkiye'sinde kadın bakış açısından kadınlar, pp. 367-382. İstanbul:iletișim.

Leiss, W., Kline, S. and Jhally, S.(1997/2009). Two Approaches to the Study of Advertisements. In A. Hansen (Ed.) Sage Benchmark in Social Research Methods: Mass 
Communication Research Methods, pp. 106-28. London:Sage Publications.

Mardin, S.(1991) Türk Modernleşmesi, İstanbul:iletișim.

Müftüler-Bac, M.(1999) 'Turkish women's predicament', in Women's studies international forum, vol. 22/3, pp. 303-315. Pergamon.

Sancar, S. and Bulut, A.(2006) 'Turkey: Country gender profile report', Available: http:// www.jica.go.jp/english/operations/thematic_issues/gender/background/pdf/eo6tur.pdf, [21 Dec 2013].

Sandıkçı, O. and Ger, G.(2007) 'Constructing and representing the Islamic consumer in Turkey' Fashion Theory: The Journal of Dress, Body \& Culture, vol.11(2/3), pp. 189-210. Berg. Schudson, M.(1989) 'Historical roots of consumer culture', in Howland R. and Wilcox Lincolnwood G. B. (ed.), Advertising in Society: Classic and contemporary readings on advertising role in society, pp. 42-72. Illinoi:NTC Business Books.

Toktaș, S.(2002) 'Engendered emotions: Gender awareness of Turkish women mirrored through regrets in the course of life', Women's Studies International Forum, vol.25/4, pp. 423-431. Pergamon.

Yavuz, S.(2013) 'Türk toplumunun tüketim toplumuna dönüșümünde reklamcılığın rolü' Iletișim Kuram ve Araștırma Dergisi, vol.36, pp. 219-240.

Yiğit, Z.(2008) 'Yavuz Turgul filmelerinde değișim olgusu', Sosyoloji Notları, pp. 67-73. 